\title{
FORMULASI GRANUL EFFERVESCENT EKSTRAK ETANOL DAUN JAMBU BIJI (Psidium guajava L.)
}

\section{FORMULATION EFFERVESCENT GRANULE OF ETHANOL EXTRACT GUAVA LEAF (Psidium guajava L.)}

\author{
Lela Sulastri, Rizal Miftah Fariz, Yayan Rizikiyan \\ Akademi Farmasi Muhammadiyah Cirebon \\ Email :lelasulastri79@yahoo.co.id
}

\begin{abstract}
ABSTRAK
Daun jambu biji (Psidium guajava (L.)) mengandung turunan flavonoid yaitu quercetin yang bersifat sebagai antibakteri. Dimana pada penelitian ini daun jambu biji dibuat dalam bentuk sediaan granul effervescent. Selain untuk membuat sediaan granul effervescent ekstrak daun jambu biji (Psidium guajava (L.)), penelitian ini juga bertujuan untuk mengetahui bagaimana pengaruhnya menggunakan kombinasi asam, basa dan pengikat yaitu asam sitrat-asam tartrat, natrium bikarbonat dan pulvis gummi arabicum (PGA) dengan variasi konsentrasi 5:5:10:0,5 ; 5:10:5:1 ; 2,5:7,5:10:1,5 variasi konsentrasi tersebut akan diuji terhadap sifat fisik granul, uji kadar air, bobot jenis (BJ), sifat alir, indeks kompresibilitas, $\mathrm{pH}$, waktu melarut dan uji respon kesukaan pada 30 panelis. Dari hasil penelitian di peroleh sifat fisik dengan bentuk granul. Berdasarkan hasil pengujian uji kadar air, bobot jenis (BJ), sifat alir, indeks kompresibilitas dan waktu melarut memperoleh hasil yang memenuhi syarat. Dan untuk pH tidak memenuhi syarat karena menggunakan kombinasi 2 asam. Untuk uji respon kesukaan pada 30 panelis aspek warna lebih disukai formula 1, aspek rasa lebih disukai formula 2 dan 3, dan aspek aroma lebih disukai formula 2 dan 3. Setelah dilakukan penelitian dengan kombinasi asam, basa dan pengikat yaitu asam sitrat-asam tartrat, natirum bikarbonat dan PGA granul effervescent dapat diformulasikan dengan hasil yang baik.
\end{abstract}

Kata Kunci: granul effervescent, daun jambu biji, formulasi daun jambu biji

\begin{abstract}
Guava leaf (Psidium guajava L.) contains flavonoid derivatives is quercetin as anti bacterial. In this research guava leaves are made in dosage form effervescent granule. Besides making effervescent granule of ethanol extract guava leaf ((Psidium guajava $\mathrm{L}$. $)$ ), this research also aims to know how its influence using combination of acid, base and binder that is citric acidtartrat acid, sodium bicarbonate and pulvis gummi arabicum (PGA) with variation of concentration 5:5:10:0,5; 5:10:5:1 ; 2,5:7,5:10:1,5, variation of the concentrations of citric acid-acid tartrate, sodium bicarbonate, and PVP against physical properties of granule, granule tested water content, type weights, flow properties, kompresibilitas index, $\mathrm{pH}$, time dissolves and test response favorite of 30 panelists. From this research in obtaining physical properties with granule form. Based on the results of the study concluded that the granule tested water content, type weights, flow properties, kompresibilitas index, time dissolves get qualified results. And for $\mathrm{pH}$ not qualified because using combination of 2 acid. For test response favorite of 30 panelists the color aspect is preferably the formula 1 , the taste aspect is preferably the formula 2 and 3 , and the aroma aspect is preferably the formula 2 and 3. After Conducted research combination of acid, base and binder that is citric acidtartrat acid, sodium bicarbonate and pulvis gummi arabicum (PGA) effervescent of granule can formulated with good results.
\end{abstract}

Keywords: effervescent of granule, guava leaf, guava leaf formulation 


\section{PENDAHULUAN}

Diare merupakan salah satu masalah kesehatan yang masih menjadi penyebab utama tingginya morbiditas dan mortalitas di negara berkembang termasuk di Indonesia.Berdasarkan etiologinya, penyakit diare dapat disebabkan oleh mikroorganisme seperti bakteri, virus dan protozoa. Untuk pengobatan diare menggunakan obat dengan bahan attapulgite dan pectin(Fratiwi, 2015), ataupun antibiotik seperti cotrimoxazole. Alternatif pengobatan lain adalah dengan obat tradisional. Alternatif pengobatan yang banyak digunakan di kalangan masyarakat adalah dengan memanfaatkan tanaman herbal. Beberapa tanaman herbal yang telah banyak digunakan oleh masyarakat sebagai anti diare terdiri dari Aegle marmelos, Cyperus rotundus, Psidium guajava L., dan Zingiber officinale (Fratiwi, 2015).

Menurut penelitian yangdilakukan oleh Tannaz (2014), jambu biji terutama bagian daun, memiliki efektifitas yang lebih tinggi dibandingkan dengan beberapa tanaman lain yang digunakan sebagai anti diare. Salah satu bahan aktif yang terkandung dalam daun jambu bijiyang memiliki perananpaling efektif sebagai antidiare adalah flavonoid. Senyawa turunan flavonoid yang terkandung dalam daun jambu bijiadalahquercetin (John dkk., 2008). Dimana kandungan quercetin yang terdapat dalam daun jambu biji sekitar 0,98-1,12\% (Hayani dkk., 2001). Ekstrak daun jambu bijidapat diformulasi dalam beberapa bentuk sediaan salah satunya adalah granul effervescent. Beberapa keuntungan sediaan granul effervescent adalah penyiapan larutan dalam waktu seketika mengandung dosis yang tepat, penggunaannya lebih mudah dan dapat diberikan kepada orang yang mengalami kesulitan menelan tablet atau kapsul (Dewi dkk., 2014).

Granul effervescent harus mempunyai daya pengikat untuk mempertahankan karakteristik granul supaya sesuai persyaratan yang ditentukan. Pulvis Gummi Arabicum (PGA) sering digunakan sebagai bahan pengikat, karena bahan pengikat PGA mempunyai daya ikat yang lebih kuat dibanding pengikat lain, mampu menghasilkan granul yang memenuhi persyaratan seperti sifat alir dan sifat fisik (Indriani, 2009). Dalam pembuatan granul effervescent memerlukan komponen penting seperti asam dan basa. Sumber asam yang digunakan asam sitrat dan asam tartrat sedangkan sumber basa yang digunakan natrium bicarbonate. Pada penelitian Noerwahid (2016), diformulasikan kombinasi ekstrak kulit manggis dan buahtomat dalam bentuk granul effervescent dengan menggunakan berbagai variasi konsentrasi asam, basa dan pengikat yaitu asam sitrat-asam tatrat, natrium bikarbonat dan PVP yang akan di uji terhadap sifat fisik granul, uji kadar air, bobot jenis (BJ), sifat alir, indeks kompresibilitas, $\mathrm{pH}$, waktu melarut dan uji respon rasa dari granul tersebut. Pada penelitian Aulia (2016) ekstrak etanol daun jambu biji digunakan sebagai antidiare dalam bentuk tablet, dengan jumlah ekstrak yang digunakan yaitu $250 \mathrm{mg}$.

Pada penelitian ini ekstrak etanol daun jambu biji dengan jumlah ekstrak yang sama yaitu $250 \mathrm{mg}$ akan diformulasikan menjadi granul effervescent dengan menggunakan variasi konsentrasi asam, basa dan pengikat yaitu asam sitrat-asam tartrat, natrium bikarbonat, PGA 5:5:10:0,5 ; 5:10:5:1 ; 2,5:7,5:10:1,5 variasi konsentrasi tersebut akan diuji terhadap sifat fisik granul, uji kadar air, bobot jenis (BJ), sifat alir, indeks kompresibilitas, $\mathrm{pH}$, waktu melarut dan uji respon kesukaan dari granul tersebut. Dengan tujuan penelitian yaitu untuk mengetahui apakah ekstrak etanol daun jambu biji dapat diformulasikan sebagai granul effervescent dengan komponen asam, basa dan pengikat yaitu asam sitrat-asam tartrat, natrium bikarbonat dan PGA dan untuk mengetahui sifat fisik, sifat kimia dan respon kesukaan dari granul effervescent ekstrak etanol daun jambu biji yang menggunakan berbagai variasi kombinasi asam,basa dan pengikat tersebut. 


\section{METODE PENELITIAN}

\section{Alat dan Bahan}

Alat yang digunakan dalam penelitian ini adalah piknometer, $\mathrm{pH}$ meter, alat uji laju alir/flow tester; alat uji kompresibilitas (tap density tester). Bahan yang digunakan dalam penelitian ini adalah ekstrak daun jambu biji yang diperoleh dengan membeli dari PT. Herba Indo Plant dengan metode maserasi dengan etanol 70\%. Dengan menggunakan kombinasi bahan asam basa dan pengikat yaitu asam sitrat (Cv. Mustika Lab.)-asam tartrat(PT. Merck), natrium bikarbonat (PT. Bratachem), PGA(Cv. Mustika Lab.) 5:5:10:0,5 ; 5:10:5:1 ; 2,5:7,5:10:1,5. Bahan yang digunakan dalam sediaan dengan spesifikasi pro teknis.

\section{Jalannya Penelitian}

1. Memperoleh Ekstrak Daun Jambu Biji

Ekstrak daun jambu biji diperoleh dengan membeli dari PT. Herba Indo Plant dengan proses ekstraksinya yaitu maserasi dengan pelarut etanol $70 \%$.

2. Pembuatan Granul Effervescent Ekstrak Etanol Daun Jambu Biji

Granul Asam

Masukkan ekstrak etanol daun jambu biji dalam mortir, menambahkan asam tartat gerus hingga homogen, menambahkan asam sitrat gerus hingga homogen, menambahkan sebagian laktosa gerus hingga homogen, menambahkan sebagian PGA dengan di semprot larutan PGA sedikit demi sedikit sehingga masa menjadi kempal, kemudian ayak dengan ayakan mesh 16 , granul basah kemudian oven $40^{\circ} \mathrm{C}$ selama 18 jam, ayak kembali dengan mesh 16 (Granul asam).

\section{Granul Basa}

Masukkan natrium bikarbonat gerus, menambahkan aspartame gerus hingga homogen, menambahkan sisa laktosa gerus hingga homogen, menambahkan sisa PGA dengan di semprot larutan PGA sedikit demi sedikit sehingga masa menjadi kempal, kemudian ayak dengan ayakan mesh 16 , granul basah kemudian oven $40^{\circ} \mathrm{C}$ selama 18 jam, ayak kembali dengan mesh 16 (Granul basa).

Pencampuran Granul Asam dan Basa

Masukkan granul asam yang telah kering ke dalam plastik kemudian masukkan granul basa ke plastik kocok hingga homogen.

Tabel I. Formulasi granul effervescent daun jambu biji

\begin{tabular}{l|c|c|c}
\hline \multirow{2}{*}{ Komponen } & \multicolumn{3}{c}{ Formula ( mg ) } \\
\cline { 2 - 4 } & I & II & III \\
\hline \hline Ekstrak daun jambu biji & 250 & 250 & 250 \\
Effervescent mix & & & \\
o Asam sitrat & 500 & 500 & 250 \\
o Asam tartat & 500 & 1000 & 750 \\
o Natrium bikarbonat & 1000 & 500 & 1000 \\
Larutan PGA & $1 \%$ & $2 \%$ & $3 \%$ \\
$\quad$ Aspartam & $(50)$ & $(100)$ & $(150)$ \\
Laktosa & 300 & 300 & 300 \\
$\quad$ Jumlah & 2400 & 2350 & 2300 \\
Keterangan : & 5000 & 5000 & 5000 \\
F I : Asam Sitrat : Asam Tartrat : Na. Bikarbonat : PGA & $5: 5: 10: 0,5$ \\
F II : Asam Sitrat : Asam Tartrat : Na. Bikarbonat : PGA & $5: 10: 5: 1$ \\
F III : Asam Sitrat : Asam Tartrat : Na. Bikarbonat : PGA & $2,5: 7,5: 10: 1,5$
\end{tabular}


3. Evaluasi Granul Effervescent

a. Uji Organoleptis visual.

Dilakukan pada hari ke-0 meliputi warna, bentuk, aroma dan rasa secara

b. Uji Kadar Air

Dilakukan dengan cara granul basah ditimbang sebanyak 120 gram kemudian dimasukkan ke dalam oven dan ditimbang bobotnya pada 30 menit, 60 menit, 17 jam, 18 jam kemudian dihitung LOD dan MC. Dilakukan pada hari ke-0. LOD (Loss on Drying) yaitu suatu pernyataan kadar kelembapan berdasarkan bobot basah dan MC (Moisture Content) yaitu suatu pernyataan kandungan lembab berdasarkan bobot kering.

c. Bobot Jenis (BJ)

Massa Jenis Benar $(\rho)$

Timbang piknometer kosong (a). Isi piknometer dengan air bersihkan, timbang (b), keluarkan air. Isi piknometer dengan kloroform bersihkan, timbang (c), keluarkan kloroform. Timbang sejumlah granul (x), masukkan pikno + kloroform, bersihkan, timbang (d). Hitung kerapatan kloroform, volume granul dan kerapatan granul.

Massa Jenis Nyata $(\rho B)$

Masukkan granul ke dalam gelas ukur $100 \mathrm{ml}$ sampai tepat $100 \mathrm{ml}$ (Baca skala pada gelas ukur). Keluarkan granul dari gelas ukur tadi dan timbang granul ( $\mathrm{x}$ gram). Tentukan massa jenis nyata.

Massa Jenis Mampat $(\rho \mathrm{T})$

Masukkan granul ke dalam gelas ukur $100 \mathrm{ml}$ sampai tepat $100 \mathrm{ml}$ (Baca skala pada gelas ukur). Keluarkan granul dari gelas ukur tadi dan timbang granul (x gram). Ketuk-ketuk gelas ukur, perhatikan penurunan volume granul pada gelas ukur. Hentikan pengetukan pada saat volume granul tidak berkurang lagi. Catat volume akhir granul (Baca skala pada gelas ukur y $\mathrm{ml}$ ). Tentukan massa jenis mampat.

d. Sifat Alir

Cara Langsung

Granul kering sebanyak 100 gram dimasukkan kedalam corong. Waktu alir granul ditentukan pada saat granul mulai mengalir sampai granul berhenti mengalir menggunakan stopwatch.

Cara Tidak Langsung

Ukur tinggi puncak kerucut (tumpukan granul) = rata-rata 3 pengukuran Ukur panjang diameter kerucut (tumpukan granul) $=$ rata-rata 3 pengukuran. Hitung sudut istirahatnya $(\alpha)$.

e. Indeks Kompresibilitas

Dilakukan dengan cara granul effervescent dimasukkan kedalam gelas ukur $100 \mathrm{~mL}$ dan dicatat volume sebelum dan sesudah dilakukan pengetapan. Dilakukan pada hari ke-0.Tentukan indeks kompresibilitas.

f. $\mathrm{pH}$

Dilakukan dengan menggunakan $\mathrm{pH}$ meter granul ditimbang sebanyak 5 gram dan dilarutkan dalam $150 \mathrm{ml}$ air kemudian diukur $\mathrm{pH}$ dengan $\mathrm{pH}$ meter. Dilakukan pada hari ke-0(Noerwahid, 2016). 
g. Waktu Melarut

Dilakukan dengan cara 5 gram granul effervescent dicampur dengan $100 \mathrm{~mL}$ air dengan suhu $10^{\circ} \mathrm{C}, 27^{\circ} \mathrm{C}$, dan $60^{\circ} \mathrm{C}$ kemudian dicatat waktu granul melarut sempurna (Noerwahid, 2016).

h. Uji Respon Kesukaan

Uji respon kesukaan dilakukan pada 30 panelis dengan batas usia dari 15-25 tahun untuk mengetahui bagaimana respon kesukaan granul effervescent dilakukan dengan parameter warna, rasa dan aroma. Pada uji ini panelis diberikan granul effervescent ekstrak etanol daun jambu biji yang sudah dilarutkan sebelumnya sehingga yang diterima berupa larutan effervescent ekstrak etanol daun jambu biji. Lalu panelis memberikan penilaian berdasarkan langkah dan parameter yang telah disiapkan sebelumnya pada formulir yang diberikan.

\section{Analisis Data}

Data ditampilkan dalam bentuk tabulasi kemudian dilakukan secara deskriptif.

\section{HASIL DAN PEMBAHASAN}

Granul effervescent ekstrak daun jambu biji dibuat dalam tiga formula yang dibedakan berdasarkan kombinasi asam, basa dan pengikat.

Tabel II. Evaluasi Granul Effervescent Ekstrak Etanol Daun Jambu Bji

\begin{tabular}{|c|c|c|c|c|}
\hline \multirow{2}{*}{\multicolumn{2}{|c|}{ Evaluasi }} & \multicolumn{3}{|c|}{ Formula } \\
\hline & & I & II & III \\
\hline \multirow[t]{5}{*}{ Organoleptis } & Warna & Coklat abu-abu & Putih abu-abu & Putih abu-abu \\
\hline & Bentuk & Granul & Granul & Granul \\
\hline & Aroma & Tidak Berbau & Tidak Berbau & Tidak Berbau \\
\hline & Rasa & Asam Sedikit & Asam Lebih & Asam Sedikit \\
\hline & & Manis & Manis & Lebih Manis \\
\hline \multirow{2}{*}{ Kadar Air } & LOD (\%) & 4,2854 & 3,1517 & 3,6265 \\
\hline & $\mathrm{MC} \quad(\%)$ & 4,4772 & 3,2543 & 3,7630 \\
\hline \multirow{3}{*}{$\begin{array}{l}\text { Bobot Jenis } \\
\text { (BJ) }\end{array}$} & BJ Benar $(\mathrm{g} / \mathrm{ml})$ & 1,7086 & 1,6889 & 1,7369 \\
\hline & BJ Nyata (g/ml) & 0,030166 & 0,0300 & 0,0301 \\
\hline & BJ Mampat (g/ml) & 0,0335 & 0,0341 & 0,0339 \\
\hline \multirow{2}{*}{ Sifat Alir } & Langsung (g/s) & 9,0009 & 7,3367 & 8,0192 \\
\hline & $\begin{array}{l}\text { Tidak Langsung } \\
\left(\alpha^{0}\right)\end{array}$ & 15,8249 & 16,3139 & 17,7401 \\
\hline \multirow{2}{*}{\multicolumn{2}{|c|}{$\begin{array}{l}\text { Indeks } \\
\text { Kompresibilitas (\%) }\end{array}$}} & 9,9522 & 12,0146 & 10,9203 \\
\hline & & & & \\
\hline \multicolumn{2}{|c|}{$\mathrm{pH}$} & 4,63 & 3,66 & 3,59 \\
\hline \multirow{4}{*}{$\begin{array}{l}\text { Waktu Melarut } \\
\text { (detik) }\end{array}$} & $10^{\circ} \mathrm{C}$ & 190 & 120 & 240,05 \\
\hline & $27^{\circ} \mathrm{C}$ & 69 & 90 & 95 \\
\hline & $60^{\circ} \mathrm{C}$ & 130 & 135 & 149 \\
\hline & kontrol 147 detik & & & \\
\hline
\end{tabular}

Pada formula pertama dengan variasi konsentrasi 0,5:0,5:1 dengan pengikat yang digunakan $1 \%$, pada formula kedua dengan variasi konsentrasi $0,5: 1: 0,5$ dengan pengikat 
yang digunakan $2 \%$, pada formula ketiga dengan variasi konsentrasi 0,25:0,75:1 dengan pengikat yang digunakan 3\%. Ekstrak daun jambu biji berfungsi sebagai zat aktif yag didalamnya terkandung senyawa turunan flavonoid yaitu quercetin (Hapsari, 2011). Menurut penelitian Tachakittirungroda dkk (2007) quercetin diklaim berpotensi sebagai antidiare dan antioksidan.

Dalam granul effervescent terdapat asam dan basa, asam yang digunakan asam sitrat dan asam tartrat yang merupakan komponen asam yang biasa digunakan dalam granul effervescent. Komponen basa yang digunakan adalah natrium bikarbonat yang pada sediaan effervescent dapat meningkatkan kadar total padatan terlarut dan dapat memperbaiki rasa (Murdianto dan Syahrumsyah, 2012). Aspartam dalam formula granul effervescent berfungsi sebagai pemanis yang merupakan bahan tambahan mudah larut dalam air agar tidak meninggalkan residu (Lindberg dkk, 1992). PGA (Pulvis Gummi Arabicum) berfungsi sebagai pengikat yang memiliki kelarutan yang tinggi dan higroskopis. PGA juga mempunyai daya pengikat yang lebih kuat dibandingkan pengikat yang lain dan menghasilkan granul yang memenuhi syarat sifat alir dan fisik. Laktosum berfungsi sebagai pengisi yang dapat menjamin granul memiliki ukuran atau masa yang dibutuhkan (Voigt, 1984).

Kadar air berdasarkan hasil pemeriksaan Loss On Drying (LOD) dan Moisture Content (MC) dari granul effervescent yang dibuat formula I memiliki nilai 4,2854\% dan 4,4772\%; formula II memiliki nilai 3,1517\% dan 3,2543\%; sedangkan formula III memiliki nilai 3,6265\% dan 3,7630\%. Kadar air dari ke III formula granul berkisar 3-4\% hal ini menunjukan bahwa granul tersebut memiliki kadar air yang baik karena sesuai dengan kandungan kadar air yang baik yaitu 2-5\% (Dewi, 2015). Kadar air yang cukup kecil dalam granul dapat menghindari reaksi effervescent dini dan sticking. Kadar air yang cukup tinggi dalam granul dapat meningkatkan resiko granul melekat pada punch dan die saat pencetakan, dan dapat menyebabkan terjadinya reaksi kimia yang dapat membuat granul effervescent tidak stabil. Kadar air yang rendah baik untuk penyimpanan sediaan dalam jangka waktu yang lebih lama, sedangkan kadar air yang tinggi merupakan media yang baik untuk pertumbuhan mikroorganisme seperti jamur.

Bobot jenis merupakan suatu analisis yang digunakan sebagai salah satu metode analisis yang berperan dalam menentukan tingkat kelarutan/daya larut suatu zat (Juniarti, 2009). Pemeriksaan ini dilakukan dengan cara metode piknometer untuk mengukur bobot jenis baik bobot jenis benar, bobot jenis nyata dan bobot jenis mampat yang dihitung berdasarkan kerapatan granul effervescent yang telah dibuat. Hasil pemeriksaan granul effervescent yang telah diperoleh dari hasil bobot jenis benar, bobot jenis nyata dan bobot jenis mampat yang pada formula I adalah $1,7086 \mathrm{~g} / \mathrm{ml}: 0,030166 \mathrm{~g} / \mathrm{ml}: 0,0335 \mathrm{~g} / \mathrm{ml}$; formula II adalah $1,6889 \mathrm{~g} / \mathrm{ml}: 0,0300 \mathrm{~g} / \mathrm{ml}: 0,0341 \mathrm{~g} / \mathrm{ml}$; sedangkan formula III adalah $1,7369 \mathrm{~g} / \mathrm{ml}: 0,0301 \mathrm{~g} / \mathrm{ml}: 0,0339 \mathrm{~g} / \mathrm{ml}$.

Sifat alir dapat diperiksa dengan 2 cara yaitu cara langsung dan tidak langsung. Dengan cara langsung seharusnya memiliki nilai kurang dari $10 \mathrm{~g} / \mathrm{s}$ Dimana dari hasil pemeriksaan yang telah dilakukan dengan cara langsung diperoleh formula I adalah 9,0009 $\mathrm{g} / \mathrm{s}$; formula II adalah 7,3367 g/s; sedangkan formula III adalah 8,0192 g/s. Dan hasil pemeriksaan dengan cara tidak langsung diperoleh formula I adalah $15,8249 \alpha^{\circ}$; formula II

adalah $16,3139 \alpha^{\circ}$; sedangkan formula III adalah 17,7401 $\alpha^{\circ}$.

Sifat alir yang dihasilkan dengan cara langsung kurang dari $10 \mathrm{~g} / \mathrm{s}$ ini dikarenakan kelembaban ruangan pada proses pembuatan granul yang $65 \%$ pada suhu $26,5^{\circ} \mathrm{C}$ yang dimana kelembapan relatif yang ideal pada pembuatan granul effervescent adalah $25 \%$ pada suhu $20-25^{\circ} \mathrm{C}$ (Noerwahid, 2016). Hasil pemeriksaan sangat baik dan memenuhi syarat yang telah ditentukan. Dimana pemeriksaan ini bergantung oleh bentuk granul, suhu dan kelembapan ruangan. Bentuk granul yang seragam mempengaruhi pada penelitian berikutnya bila dibentuk pada sediaan tablet saat proses pencetakan. Untuk suhu dan kelembapan yang terlalu tinggi ataupun terlalu rendah akan menyebabkan kecepatan alir granul semakin 
lambat karena granul yang terlalu basah atau kering dapat mempengaruhi sifat alir granul tersebut (Ardiani, 2012).

Hasil indeks kompresibilitas granul effervescent formula I adalah 9,9522\%, formula II adalah $12,0146 \%$ dan formula III adalah 10,9203\% dimana hasilnya sesuai dengan syarat indeks kompresibilitas formula I dan III yaitu sangat baik dan formula II yaitu baik. Dari hasil pemeriksaan ini juga kita dapat mengetahui granul baik apabila dibuat dalam sediaan tablet.

pH dari granul effervescent yang dibuat tidak memenuhi syarat dimana formula I nilai $\mathrm{pH} 4,63$; formula II nilai $\mathrm{pH} 3,66$; sedangkan formula III nilai $\mathrm{pH} 3,59$. Dimana $\mathrm{pH}$ idealnya adalah 7. Hal ini disebabkan karena menggunakan kombinasi 2 asam pada tiap formulanya sehingga disarankan sebelum mengkonsumsinya perlu makan terlebih dahulu atau tidak saat perut kosong.

Waktu melarut merupakan pemeriksaan yang digunakan untuk mengetahui berapa lama granul tersebut melarut dalam air dan dari hasil pemeriksaan yang telah dilakukan semua formula memiliki waktu larut yang kurang dari 5 menit dan itu memenuhi dari syarat yang telah ditentukan.

Respon kesukaan yang telah dilakukan pada 30 panelis diperoleh hasil berdasarkan aspek warna, rasa dan aroma. Pada formula I, II dan III diperoleh hasil aspek warna yang disukai formula I, untuk aspek rasa yang disukai formula II dan III, sedangkan aspek aroma yang disukai formula II dan III. Sehingga dari semua formula yang telah dilakukan respon kesukaan pada 30 panelis aspek warna yang disukai formula I, aspek rasa yang disukai formula II dan III dan aspek aroma yang disukai formula II dan III.

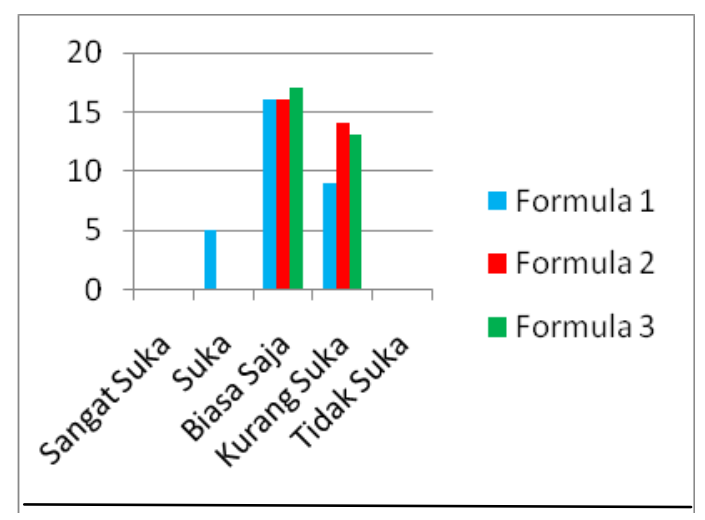

Gambar 1. Respon Kesukaan Aspek Warna

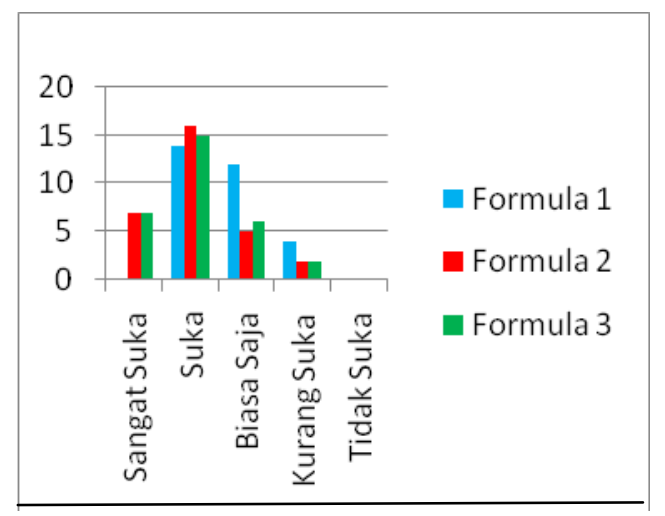

Gambar 2. Respon Kesukaan Aspek Rasa

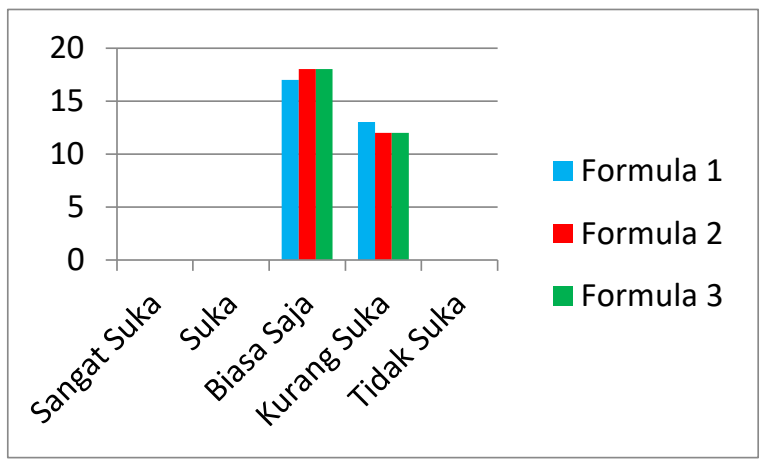

Gambar 3. Respon Kesukaan Aspek Aroma 


\section{KESIMPULAN}

Ekstrak etanol daun jambu biji dapat dibuat menjadi granul effervescent. Sifat fisik dan kimia granul effervescent formula I adalah warna coklat keabu-abuan, tidak berbau, bentuk granul, rasa asam sedikit manis; kadar air LOD 4,2854\% dan MC 4,4772\%; bobot jenis benar $1,7086 \mathrm{~g} / \mathrm{ml}$, bobot jenis nyata $0,030166 \mathrm{~g} / \mathrm{ml}$ dan bobot jenis mampat $0,0335 \mathrm{~g} / \mathrm{ml}$; sifat alir $9,0009 \mathrm{~g} / \mathrm{s}$ dengan sudut diam 15,8249 $\alpha^{\circ}$;

indeks kompresibilitas 9,9522\%; $\mathrm{pH} 4,63$ dengan waktu melarut pada suhu $10^{\circ} \mathrm{C} 190$ detik, $27^{\circ} \mathrm{C} 69$ detik dan $60^{\circ} \mathrm{C} 130$ detik. Sifat fisik dan kimia granul effervescent formula II adalah warna putih keabu-abuan, tidak berbau, bentuk granul, rasa asam lebih manis; kadar air LOD 3,1517\% dan MC 3,2543\%; bobot jenis benar 1,6889 $\mathrm{g} / \mathrm{ml}$, bobot jenis nyata $0,0300 \mathrm{~g} / \mathrm{ml}$ dan bobot jenis mampat $0,0341 \mathrm{~g} / \mathrm{ml}$; sifat alir $7,3367 \mathrm{~g} / \mathrm{s}$ dengan sudut diam 16,3139 $\alpha^{\circ}$; indeks kompresibilitas 12,0146\%; pH

4,66 dengan waktu melarut pada suhu $10^{\circ} \mathrm{C} 210$ detik, $27^{\circ} \mathrm{C} 90$ detik dan $60^{\circ} \mathrm{C} 135$ detik. Sifat fisik dan kimia granul effervescent formula III adalah warna putih keabuabuan, tidak berbau, bentuk granul, rasa asam sedikit lebih manis; kadar air LOD $3,6265 \%$ dan MC 3,7630\%; bobot jenis benar $1,7369 \mathrm{~g} / \mathrm{ml}$, bobot jenis nyata 0,0301 $\mathrm{g} / \mathrm{ml}$ dan bobot jenis mampat $0,0339 \mathrm{~g} / \mathrm{ml}$; sifat alir 8,0192 g/s dengan sudut diam $17,7401 \alpha^{\circ}$; indeks kompresibilitas $10,9203 \%$; pH 3,59 dengan waktu melarut pada

suhu $10^{\circ} \mathrm{C} 240,05$ detik, $27^{\circ} \mathrm{C} 95$ detik dan $60^{\circ} \mathrm{C} 149$ detik.Respon kesukaaan, aspek warna yang disukai formula I, aspek rasa yang disukai formula II dan III dan aspek aroma yang disukai formula II dan III.

\section{DAFTAR PUSTAKA}

Aulia, W.F. 2016. Formulasi Tablet Ekstrak Etanol Daun Jambu Biji (Psidium guajava L). Jurnal Sekolah Tinggi Farmasi Indonesia Yayasan Perintis Padang, 5-10.

Ardiani, W.P. 2012. Perbandingan Variasi Suhu Pengeringan Granul Terhadap Kadar Air dan Sifat Fisis Tablet Parasetamol. Jurnal Fakultas Matematika Dan Ilmu Pengetahuan Alam, 42-44.

Dewi, R., Iskandarsyah dan Dewi, O. 2014. Uji Stabilitas Fisik Formula Krim yang Mengandung Ekstrak Kacang Kedelai (Glycine max). Jurnal Universitas Indonesia, 5-8.

Fratiwi, Y. 2015. The Potential of Guava Leaf (Psidium guajava L.) For Diarrhea. Jurnal Universitas Lampung vol $4: 2-5$.

Hapsari, R. 2011. Studi Isolasi dan Penentuan Struktur Molekul Senyawa Kimia Dalam Fraksi Asam Dari Daun Jambu Biji Lokal Daging Buah Merah (Psidium guajava L.).Jurnal Universitas Indonesia, 7-20.

Hayani, E., Sri, Y. dan Laba, U. 2001. Kadar Tanin dan Quercetin Tiga Tipe Daun Jambu Biji (Psidium guajava). JurnalBalai Penelitian Tanaman Rempah dan Obat vol 2 : 303.

Indriani, A. 2009. Pengaruh Kadar Bahan Pengikat Pulvis Gum Aarabicum Terhadap Sifat Fisik Tablet Effervescent Ekstrak Etanol Benalu Teh (Scurulla atropurpurea [Bl.] Dans.). Jurnal Universitas Muhammadiyah Surakarta, 21-22.

John, A.O.O., Emmanuel, O.A. dan Witness, D.H.C. 2008. Antidiarrhoeal activity of Psidium guajava L. Linn. (Myrtaceae) leaf aqueous extract in rodents. Journal Smooth Muscle Res. Vol $6: 195-207$.

Juniarti, N.2009. Penetapan Bobot Jenis dan Rapat Jenis. Jurnal Universitas Hasanuddin, 26. 
Murdianto, W. dan Syahrumsyah, H. 2012. Pengaruh Natrium Bikarbonat Terhadap Kadar Vitamin C Total Padatan Terlarut dan Nilai Sensoris dari Sari Buah Nanas Berkarbonasi, Jurnal Teknologi Pertanian, 2-5.

Lindberg, N., Engfors, H. dan Ericsson, T. 1992. Encyclopedia of Pharmaceutical Technology, Effervescent Pharmaceutical in Swarbricck. J., Boylan, J.C.. Vol 5:4571, Marcel Dekker, Inc., New York.

Noeurwahid, A. 2016. Formulasi Granul Eeffervescent Antioksdian Kombinasi Ekstrak Kuit Manggis (Garcinia mangostana L.) Dan Buah Tomat (Solanum lycopersicum). Jurnal Universitas Muhammadiyah Surakarta, 5-10.

Tachakittirungroda, R., Roeka, S., Putra, W.L. 2007. Identifikasi flavonoid untuk antioksidan dan antidiare. Jurnal Universitas Muhammadiyah Prof. Dr. Hamka vol 2 :381-388.

Tannaz, J.B., Wildan, J., Hakim, P. 2014. Bactericidal effect of selected antidiarrhoeal medicinal plants on intracellular heat-stable eterotoxin-producing Escherichia coli. Mumbai :Indian Journal Pharmaceutical Sciences vol 3 : 229-35.

Voigt. 1984. Buku Ajar Teknologi Farmasi. Diterjemahkan oleh Soendani Noeroto S.,UGM Press, Yogyakarta. Hal: 337-338. 